\title{
SPECYFIKACJA JAKO INSTRUMENT KONTEKSTUALIZACJI AKTU TŁUMACZENIOWEGO - MIĘDZY TEORIĄ A PRAKTYKA DYDAKTYKI PRZEKŁADU
}

Zarys treści: Pojęcie zlecenia (Auftrag) wprowadzone zostało do badań przekładoznawczych przez teorię skoposu, ukierunkowaną funkcjonalistycznie i podkreślającą rolę celu tłumaczenia. Anglojęzyczna literatura przedmiotu posługuje się głównie terminem translation brief. W polskiej tradycji pojawiają się różne określenia, od opisowych „instrukcja zleceniodawcy” po zapożyczenie „translation brief”; w artykule postulujemy zastosowanie terminu „specyfikacja”. W dydaktyce przekładu uważana jest ona za niezbędny element każdego zadania tłumaczeniowego (por. Nord 1988/2005). Umiejętność odczytywania i interpretowania specyfikacji, często podawanej w formie implicytnej, stanowi ważny aspekt nauczania tłumaczenia. W kontekście oceny przekładu niektórzy badacze postulują wyprowadzanie kryteriów oceny właśnie ze specyfikacji, chociaż trochę inaczej rozumianej (specification approach, Hague i in. 2011). Celem artykułu jest omówienie koncepcji specyfikacji w teorii dydaktyki przekładu oraz zestawienie jej z polską praktyką dydaktyczną, do czego posłuży analiza wybranych podręczników tłumaczeniowych oraz przeprowadzone badania empiryczne.

\section{Przegląd terminologiczny}

Ctwierdzenie, że gdy tłumaczymy, tłumaczymy dla kogoś, w konkretnym celu i w konkretnej sytuacji komunikacyjnej, wydaje się rzeczą oczywistą. Naukowe zainteresowanie tłumaczeniem jako działalnością teleologiczną, czyli celową, rozpropagowała teoria skoposu. Wprowadziła ona do badań przekładoznawczych termin Auftrag, czyli zlecenie (Gentzler 2001: 73). Oznacza on instrukcje od klienta, które tłumacz otrzymuje do wykonania danego tłumaczenia. W anglojęzycznej literaturze przedmiotu funkcjonują 
głównie dwa odpowiedniki: (translation) brief i commission. Pym (2011: 76-77) komentuje je w następujący sposób:

„Brief” bardziej przypomina to, co adwokat otrzymuje od klienta: ogólny, otwarty mandat do osiągnięcia celu lub rozwiązania problemu. Vermeer pisząc po angielsku posługuje się terminem „commission”, który przypomina to, co otrzymuje artysta malarz: „wypełnij tę przestrzeń tak, jak ci się podoba”.

Występuje również termin job description, używany przez Gouadeca, który uważa, że „to klient powinien ustalić jak najwięcej aspektów tekstu, który ma powstać" (Pym 2011: 77). Pym sugeruje, że należy posługiwać się terminem instructions, ponieważ w branży tłumaczeniowej nie używa się właściwie żadnego $\mathrm{z}$ wymienionych wcześniej terminów (Pym 2007: 77).

W polskiej terminologii przekładoznawczej używane są takie określenia, jak: „wymagania zleceniodawcy” (Skibińska 2001: 107), „instrukcje zleceniodawcy” (Brzozowski 2011: 78), „raport tłumaczeniowy” (Piotrowska 2007a: 182), „briefing” (Albin 2011: 89), a także nieuzasadnione moim zdaniem zapożyczenie translation brief (Grygoruk 2005). Określenie Brzozowskiego najbliższe jest propozycji Pyma. Używam słowa „określenie” celowo, ponieważ pozostaje do ustalenia, czy w polskim kontekście faktycznie mamy do czynienia z terminem. Wydaje się, że tylko „raport tłumaczeniowy” Piotrowskiej użyty jest terminologicznie i zdefiniowany przez wymienienie jego elementów składowych. W niniejszym artykule chciałabym zaproponować termin „specyfikacja tłumaczeniowa”, żeby podkreślić związek tłumaczenia rozumianego jako zadanie tłumaczeniowe wymagające podejmowania decyzji z kontekstem jego realnego, często rynkowego, odbioru i recepcji. Specyfikacja to zatem zbiór mniej lub bardziej eksplicytnych instrukcji do wykonania zlecenia tłumaczeniowego w taki sposób, żeby spełniało wymagania klienta/ zleceniodawcy. W kontekście dydaktycznym terminem specyfikacji można posługiwać się w zadaniach, które są realistyczne w kontekście zawodowym i symulują pracę tłumacza na rynku tłumaczeniowym dla podkreślenia rzeczywistych, pragmatycznych i funkcjonalistycznych uwarunkowań aktu tłumaczeniowego.

\footnotetext{
${ }^{1}$ Cytaty ze źródeł w języku innym niż polski podano w tłumaczeniu autorki artykułu.
} 


\section{Specyfikacja tłumaczeniowa w teorii dydaktyki przekładu}

W teorii dydaktyki przekładu, tak jak w funkcjonalistycznych podejściach do tłumaczenia, do specyfikacji tłumaczeniowej przywiązuje się bardzo dużą wagę (por. Klein-Braley 1996: 24-25; Reiß, Vermeer 1984: 101; Schäffner, Wiesemann 2001: 18), ponieważ informując o kontekście komunikacyjnym, ukierunkowuje ona decyzje tłumacza i umożliwia ocenę tłumaczenia. Zajmuje ona szczególne miejsce $\mathrm{w}$ analizie tekstu ukierunkowanej na przekład, którą propaguje Christiane Nord. Według badaczki specyfikacja tłumaczeniowa powinna zawierać jak najwięcej informacji o „czynnikach sytuacyjnych recepcji planowanego tekstu docelowego” (Nord 2005: 11), takich jak:

- (zamierzone) funkcje tekstu,

- adresat (adresaci) lub potencjalni odbiorcy,

- czas i miejsce recepcji tekstu,

- kanał komunikacyjny, za pomocą którego będzie odbierany tekst,

- motyw wytworzenia i recepcji tekstu.

Do tej listy warto dodać także „status tłumaczenia” (Fraser 2000: 53), np. czy będzie to tekst do publikacji, czy do komunikacji wewnętrznej w firmie. Oprócz informacji dotyczących sytuacji komunikacyjnej specyfikacja powinna zawierać informacje proceduralne, takie jak termin ukończenia zlecenia i forma przekazania tłumaczenia.

Z kolei Piotrowska (2007a: 182) precyzuje takie elementy specyfikacji, nazywanej przez badaczkę raportem tłumaczeniowym, jak:

- czas otrzymania tekstu i termin jego wykonania,

- miejsce otrzymania tekstu,

- środek przekazu,

- język źródłowy i docelowy,

- rodzaj i przeznaczenie tłumaczenia.

Warto zaznaczyć, że badaczka wprowadza określenie „raportu” w opisie studenckiego portfolio tłumaczeniowego, co uzasadnia jej wybór leksykalny.

Według Nord w sytuacji dydaktycznej każde zadanie tłumaczeniowe powinno zawierać mniej lub bardziej eksplicytny opis zlecenia, czyli specyfikację, a umiejętność jej odkodowywania i interpretacji powinna stanowić część zajęć z tłumaczenia praktycznego (2006: 18). Podobnego zdania są inni badacze: „nauczyciele przekładu powinni podawać specyfikację tłumaczeniową, która m.in. opisuje funkcję tłumaczenia. Informacje zawarte w specyfikacji będą wpływały na wszystkie decyzje studentów podczas procesu tłumaczenia, a także na decyzje nauczyciela co do błędów tłumaczeniowych" (Yilmaz Gümüş 2008: 214). Specyfikacja odgrywa zatem kluczową rolę także w ocenie 
wykonanego tłumaczenia (por. Hague i in. 2011; Hönig 1998) i jako instrument zarządzania jakością (Hulst, Lentz 2001: 98). W tym kontekście Nord (2006: 17) definiuje błąd tłumaczeniowy z perspektywy funkcjonalnej jako

niewypełnienie zaleceń specyfikacji tłumaczeniowej w odniesieniu do pewnych aspektów funkcjonalnych. Oznacza to, że każde tłumaczenie (Übersetzungsleistung) może zostać ocenione tylko w odniesieniu do podanego (funkcjonalnego) celu tłumaczenia. Ten cel tłumaczenia musi być tłumaczowi/tłumaczce znany.

„Pojęcie specyfikacji jest tak fundamentalne dla skutecznego i wydajnego tłumaczenia - zauważa Fraser - że wydaje się trywialne, żeby o nim pisać w badaniach nad procesem tłumaczenia" (2000: 53). To, co wydaje się jednak oczywiste z teoretycznej perspektywy przekładoznawczej, nie jest oczywistością w innych kontekstach. Jak podnosi sama badaczka, ankietowani przez nią tłumacze zawodowi w Wielkiej Brytanii zwracają uwagę na trudności z otrzymaniem odpowiedniej informacji od klientów/zleceniodawców (Fraser 2000: 53-54) i nie jest to sytuacja odosobniona (por. komentarz na temat Słowenii - Limon 2010: 34).

\section{Funkcja specyfikacji w podręcznikach ttumaczeniowych}

Czy teoretyczne założenia dotyczące wagi specyfikacji tłumaczeniowej w procesie dydaktycznym znajdują odzwierciedlenie w podręcznikach do nauki przekładu? Warto rozpocząć od uwagi, że poczucie niedosytu co do publikacji poświęconych stricte nauczaniu tłumaczenia, o którym pisze González Davies (2004: 5), pozostaje szczególnie aktualne w polskim kontekście. W Polskiej Bibliografii Przekładoznawczej (dla przekładu pisemnego) (Piotrowska 2007b) wśród publikacji skategoryzowanych jako podręczniki tłumaczeniowe (14) tylko cztery zawierają ćwiczenia do wykorzystania na praktycznych zajęciach z tłumaczenia. Skoncentrujemy się na wybranych książkach, które oferują podstawowy kurs tłumaczeniowy i zawierają ćwiczenia praktyczne. $\mathrm{W}$ obszarze tłumaczenia angielsko-polskiego do tych nielicznych ${ }^{2}$ dostępnych

2 Dostępne są także inne publikacje dotyczące kombinacji językowej angielsko-polskiej, które można sklasyfikować jako podręczniki tłumaczeniowe. Do najpopularniejszych należy zaliczyć Przekład prawny i sądowy A. Jopek-Bosiackiej z serii „Mity i rzeczywistość” PWN (2006) oraz Jak czytać i rozumieć angielskie umowy L. Berezowskiego (2008), nie zwierają one jednak ćwiczeń praktycznych. 
na polskim rynku publikacji należy zaliczyć Learning Translation, Learning the Impossible? Marii Piotrowskiej (1997) i Poradnik tłumacza Arkadiusza Belczyka (2004). W odniesieniu do języka francuskiego należy wspomnieć Inaczej mówiąc... Elżbiety Skibińskiej (2001)³.

Każdy z tych podręczników ma nieco inne założenia. Książka autorstwa Belczyka, jak wskazuje sam tytuł, to poradnik, przede wszystkim językowy w ujęciu kontrastywnym. Oprócz typowych problemów głównie natury lingwistycznej omawia również zagadnienia metodologiczne, którymi są techniki przekładu. W zdecydowanej większości ćwiczeń jednostką tłumaczeniową jest zdanie, zawierające egzemplifikację problemu przekładowego, który został wprowadzony i omówiony $\mathrm{w}$ poprzedzającym ćwiczenie rozdziale. Często zdanie zawiera informację kontekstową, np. ${ }^{4}$

Przykład (1)

Ćwiczenie 1. Zaproponuj optymalną formę przekładu następujących zdań:

a) Ich bin ein Beginner [podpis pod karykatura przemawiajacego Clintona]

b) Honey, you can't live just on Kool-Aids and Hershey Bars [mama do dziecka]

(R. 8 Tło kulturowe, Belczyk 2009: 229)

Tak jak w powyższym ćwiczeniu, najczęstszą formą pracy jest tłumaczenie zdań na język polski; niejednokrotnie są to tłumaczenia sterowane, ponieważ zawierają polecenie określające użycie odpowiedniej formy gramatycznej lub szyku zdania, np.

Przykład (2)

If you have seen Lamu, you'll easily recognize this style of architecture. [Użyj odpowiedniej formy zaimka kto.]

Be warned that they won't sell you a ticket unless you already have the visa. [Użyj prostego okolicznika i formy osobowej.]

(R. 3.4 You, Belczyk 2009: 70)

Nieliczne ćwiczenia polegające na tłumaczeniu całych tekstów lub ich fragmentów nie zawierają specyfikacji tłumaczeniowej lub bardzo ogólną,

3 Jeżeli chodzi o język rosyjski, warto odnotować wydanie Podręcznika dla tłumaczy języka rosyjskiego. Postępowanie przygotowawcze i sądowe (Jeglińska, Ndiaye 2012) w serii „Teoria i praktyka przekładu" UWM w Olsztynie. Ze względu na specjalistyczny charakter publikacji nie stanowi ona przedmiotu omówienia niniejszego artykułu.

${ }^{4}$ Przykłady zaczerpnięto z drugiego, rozszerzonego wydania Poradnika (2009). 
typu opracuj polska wersję danego tekstu (por. Belczyk 2009: 200, 210-211, 213). Jest to nie bez znaczenia dla proponowanych w kluczu tłumaczeń. Brak specyfikacji powoduje, że rozpiętość potencjalnych tłumaczeń może być spora, co skłania autora do dodawania do niektórych przekładów komentarzy z informacjami precyzującymi kontekst, które właściwie mogłyby stanowić część specyfikacji (np. Belczyk 2009: 315). Nie znając sytuacji komunikacyjnej (źródła tekstu, jego funkcji wyjściowej/docelowej, odbiorcy docelowego), trudno także ocenić konkretną propozycję tłumaczeniową i określić, na ile jest adekwatna. Jako ilustracje przytoczmy proponowane tłumaczenia dla pierwszego przykładu:

a) Jestem początkujący [trawestacja słynnej deklaracji J. Kennedy’ego w Berlinie Zachodnim: „Ich bin ein Berliner” (przyp. tłum.)],

b) Skarbie, nie możesz się żywić tylko lemoniadą i batonikami czekoladowymi.

W przykładzie a) zastosowano tłumaczenie z objaśniającym przypisem tłumacza. Warto zwrócić uwagę, że ta technika tłumaczeniowa budzi kontrowersje i w związku z tym jej stosowanie wymaga rozważnej oceny sytuacji komunikacyjnej (por. Skibińska 2009: 7). Przykładowo, do rzadkości na rynku tytułów prasowych można zaliczyć „politykę tłumaczeniową” zamieszczającego przedruki z prasy zagranicznej „Forum”, w którym przypisy tłumacza/ redakcji są normą (por. Paprocka 2009).

$\mathrm{W}$ przykładzie b), podobnie jak w a), brak informacji o adresacie, gatunku tekstu (np. czy mamy do czynienia z zapisem dialogu filmowego, czy $\mathrm{z}$ fragmentem powieści) i kontekście historycznym. Nietrudno wyobrazić sobie sytuację, w której proponowane tłumaczenie przez udomowienie i uogólnienie (Kool-Aid - lemoniada, Hershey Bars - batoniki czekoladowe) jest rozwiązaniem optymalnym, ale równie łatwo można wyobrazić sobie sytuację, gdy tak nie jest. Uzasadnienia wymaga także zastosowanie nacechowanej stylistycznie formy „żywić się".

Inny cel i układ mają pozostałe dwie książki: Learning Translation i Inaczej mówiąc... W przeciwieństwie do Poradnika wydają się adresowane do bardziej zaawansowanych adeptów przekładu, zainteresowanych elementami metodologicznymi. Obie charakteryzuje ujęcie procesualne, wyrażające się obecnością ćwiczeń z różnych etapów procesu tłumaczenia, $\mathrm{w}$ tym wielu $\mathrm{z}$ etapu analizy (np. porównawcza analiza gatunków tekstów, przewidywanie problemów tłumaczeniowych). Nie są to zatem zadania typowo tłumaczeniowe, czyli Übersetzungsleistung w ujęciu Nord. Ćwiczenia, które polegają stricte na tłumaczeniu tekstów, są opatrzone bardziej implicytnymi instruk- 
cjami w Learning Translation i eksplicytnymi w Inaczej mówiąc... Przytoczmy przykłady specyfikacji z tej ostatniej pozycji:

Przykład (3)

- Poniższy tekst ma zostać przetłumaczony na zlecenie burmistrza miasta: jest on częścią dokumentacji, z którą mają zapoznać się radni miejscy, zanim zdecydują, czy Rada Miasta podpisze umowę o współpracy z miastem francuskim (Skibińska 2001: 109).

- Poniższy tekst to instrukcja obsługi urządzenia, które firma Moulinex chce wprowadzić na rynek polski. Zgodnie z ustawą z dn. 16 kwietnia 1993 r., nakładającą na producentów i sprzedawców obowiązek opisywania towarów w języku polskim, musi on zostać przetłumaczony, przy zachowaniu układu typograficznego założonego przez producenta (Skibińska 2001: 18).

Na koniec warto zaznaczyć jeszcze jedną różnicę w założeniach, którymi kierują się trzy omawiane podręczniki. Inaczej mówiąc... to zestaw ćwiczeń, opatrzony krótkimi uwagami teoretyczno-metodologicznymi, natomiast Learning Translation zawiera obszerniejszy komentarz metodologiczny. Z kolei Poradnik poświęcony jest głównie zagadnieniom kompetencji językowej. Należy też zwrócić uwagę na lata publikacji podręczników, co nie jest bez znaczenia dla założeń metodologicznych i sposobu układu treści. Najstarszą pozycją jest Learning Translation (1 wydanie 1997), a najnowszą Poradnik (1 wydanie 2004). Jego drugie, zaktualizowane wydanie (2009) zawiera obszerniejszy materiał ćwiczeniowy, w tym więcej informacji kontekstowych niż pierwsze.

Żeby poszerzyć refleksję nad konstrukcją podręcznika tłumaczeniowego i sposobem integracji w nim specyfikacji, sięgnijmy jeszcze po przykład uznanej i popularnej serii Thinking Translation (Routledge), poświęconej przekładowi na język angielski ${ }^{5}$. Zawierający teorię dla uczących się tłumaczenia i ćwiczenia praktyczne podręcznik w założeniu przypomina Learning Translation, ale oferuje szersze opracowanie metodologii i pragmatyki tłumaczenia, co sygnalizuje już podtytuł $A$ course in translation method (podkreślenie - J.D.-G. $)^{6}$. Omawiany podręcznik jest też obszerniejszy od porówny-

${ }^{5} \mathrm{~W}$ serii Thinking Translation ukazały się edycje dotyczące tłumaczenia z takich języków jak arabski, francuski, hiszpański, niemiecki i włoski. W artykule korzystamy z wydania dla języka niemieckiego, Thinking German Translation.

${ }^{6}$ Natomiast podtytuły polskich podręczników to A course of translation from English into Polish i Tłumaczenie z francuskiego na polski. Co ciekawe, w drugim wydaniu Poradnika dla tłumacza zrezygnowano $\mathrm{z}$ obecnego $\mathrm{w}$ pierwszym rozszerzenia: $z$ angielskiego na nasze. 
wanych polskich i zawiera więcej ćwiczeń. Polecenia do wszystkich ćwiczeń mają taki sam układ. Zawierają nie tylko szczegółową specyfikację, ale również informacje kontekstowe. Podajmy przykład:

Przykład (4)

Tłumaczenie streszczające (gist translation)

Zadanie (assignment)

Otrzymałeś zlecenie przetłumaczenia, w skróconej formie, luksusowego katalogu wysyłkowego, z którego zaczerpnięto poniższy tekst wyjściowy. Tekst docelowy ma zawierać $3 / 4$ wierszy tekstu wyjściowego, w związku $\mathrm{z}$ tym powinien mieć pomiędzy 220 a 240 słów (tekst wyjściowy zawiera tylko 236, ale wiele z nich to długie composita).

Sporządź tłumaczenie wymaganej długości.

$[\ldots]$

$[\ldots]$

Informacje kontekstowe (contextual information)

Tekst stanowi wprowadzenie do długiej sekcji o nożach kuchennych w katalogu. Angielski katalog jest równie obszerny, jeśli chodzi o zakres informacji, ale bardziej ekonomiczny co do miejsca. Oba często podkreślają wysoką jakość oferowanych noży.

(Hervey i in. 2006: 14)

Jak widać, korzystający z książki otrzymują bardzo szczegółową specyfikację tłumaczeniową. Wynika to $\mathrm{z}$ funkcjonalnego podejścia do przekładu, które stanowi teoretyczne umocowanie podręcznika. „Żadne tłumaczenie nie powstaje w próżni” - piszą autorzy; „podkreślamy w tym kursie, że potrzeby odbiorcy docelowego i wymagania osoby zlecającej to główne czynniki przy podejmowaniu decyzji tłumaczeniowych" (Hervey i in. 2006: 2). Uważają oni, że rola specyfikacji tłumaczeniowej jest nie do przecenienia, ponieważ „Jednym z najważniejszych zagadnień tłumaczenia nie jest ani pewna cecha tekstowa, ani operacja tłumaczeniowa. Jest nim specyfikacja tłumaczeniowa (translation brief) - dlaczego tekst jest tłumaczony, w czyim imieniu i dla jakiego odbiorcy" (Hervey i in. 2006: 212).

Jak pokazuje analiza wybranych podręczników do nauki przekładu dostępnych na polskim rynku, zawierają one czytelne polecenia do ćwiczeń, znacznie rzadziej natomiast sformułowane explicite specyfikacje tłumaczeniowe, nie wprowadzają też koncepcji specyfikacji. Inną formułą kierują się autorzy książki Thinking German Translation, w której specyfikacja jako centralny element funkcjonalistycznych założeń teoretycznych podręcznika 
stanowi element każdego ćwiczenia. Warto te uwagi rozważyć w szerszym kontekście, pamiętając, że podręcznik tłumaczeniowy to stosunkowy nowy gatunek tekstowy. Od przywołania zaskakująco często zadawanego pytania, czy tłumaczenia można nauczyć, rozpoczynają swój podręcznik autorzy Thinking German Translation (2006: 1). Natomiast autorka Learning Translation zastanawia się w tytule swojego artykułu, czy podręcznik do tłumaczenia to przydatne narzędzie dydaktyczne, czy utopia (Piotrowska 2007c). Teoria nowoczesnej dydaktyki przekładu rozstrzygnęła te wątpliwości pozytywnie, otwarte natomiast pozostaje pytanie, jaki w praktyce ma być podręcznik tłumaczeniowy. O tym, że podręczniki takie są potrzebne, jednoznacznie informują dane z rynku wydawniczego: prawie wszystkie omawiane książki były dodrukowywane i wznawiane ${ }^{7}$.

\section{Specyfikacja tłumaczeniowa w praktyce dydaktycznej - badania empiryczne}

W jakim stopniu i jak teoretyczne założenia dydaktyki przekładu, podkreślające znaczenie specyfikacji tłumaczeniowej, znajdują odzwierciedlenie w praktyce nauczania? Do odpowiedzi na to pytanie posłużymy się wynikami badań empirycznych. Pochodzą one z badań pilotażowych nad praktyką nauczania przekładu $\mathrm{w}$ polskich uczelniach wyższych. Mają one charakter diagnostyczny i etnograficzny, a ich celem jest wyróżnienie tendencji w organizacji procesu dydaktycznego oraz w koncepcjach tłumaczenia, które nabywają studenci. Przedstawimy wycinek dotyczący interesującego nas aspektu specyfikacji tłumaczeniowej. Szczegółowe pytania badawcze są w tym zakresie następujące: Czy specyfikacja tłumaczeniowa, jak postulują badacze, stanowi integralną część zadań tłumaczeniowych? Czy studenci widzą zależność między podejmowaniem decyzji tłumaczeniowych (i łączącymi się z nimi ewentualnymi błędami w tłumaczeniu) a funkcją tłumaczenia? Jak studenci postrzegają błąd w tłumaczeniu?

Przeprowadzone badanie miało formę ankiety i objęło uczestników studiów magisterskich ${ }^{8}$, obecnie i/lub w przeszłości studiujących na kierunkach filologicznych. Zwrócono 28 ankiet z odpowiedziami, z czego przeanalizo-

\footnotetext{
7 Learning Translation - 1 wyd. 1997, 2 wyd. 2003, 3 wyd. 2010, 4 wyd. 2011; Poradnik tlumacza -1 wyd. 2004, 2 wyd. 2009; Thinking German Translation - 1 wyd. 1995, 2 wyd. 2006.

${ }^{8}$ Badania przeprowadzono wśród słuchaczy programu Artes Liberales na Uniwersytecie Jagiellońskim (2011/2012).
} 
wano 25, wypełnionych przez studentów, którzy ukończyli już jedne studia filologiczne ${ }^{9}$ i mieli praktyczne zajęcia $\mathrm{z}$ tłumaczenia.

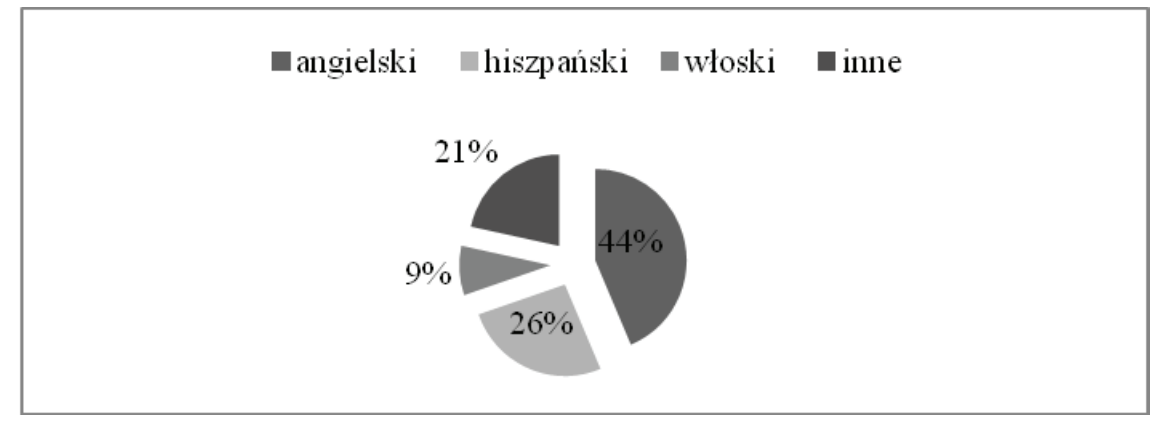

Rys. 1. Charakterystyka ankietowanych według głównego języka nauczanego w ramach studiów filologicznych

Pierwsze pytanie dotyczące specyfikacji tłumaczeniowej brzmiało:

Jak sprawdzane i oceniane były na zajęciach w czasie dotychczasowej edukacji teksty wykonanych przez Państwa tłumaczeń? Proszę zaznaczyć odpowiedni kwadrat.

Tekst do tłumaczenia był opatrzony specyfikacją tłumaczeniową (Übersetzungsauftrag/translation briefljob description). Proszę wybrać a) LUB odpowiedni kwadrat wb).
a) nie znam tego pojęcia
b)
często
czasami $\square$ nigdy

Wszyscy ankietowani zdeklarowali znajomość pojęcia specyfikacji tłumaczeniowej, ponieważ nikt nie zaznaczył odpowiedzi a). Co zaskakujące, nikt nie wybrał odpowiedzi „zawsze” lub „często”. Zdecydowana większość (82,6\% ankietowanych) czasami otrzymywała instrukcję, a aż 17,4\% nigdy (rys. 2).

Drugie pytanie dotyczyło koncepcji błędu w tłumaczeniu:

Najpoważniejszy błąd w tłumaczeniu to niewypełnienie instrukcji zlecenia tłumaczeniowego.

$\square$ zdecydowanie tak $\square$ raczej tak $\square$ nie mam zdania $\square$ raczej nie

$\square$ zdecydowanie nie

${ }^{9}$ Wymieniane kierunki objęły głównie filologie nowożytne i lingwistykę stosowaną. 


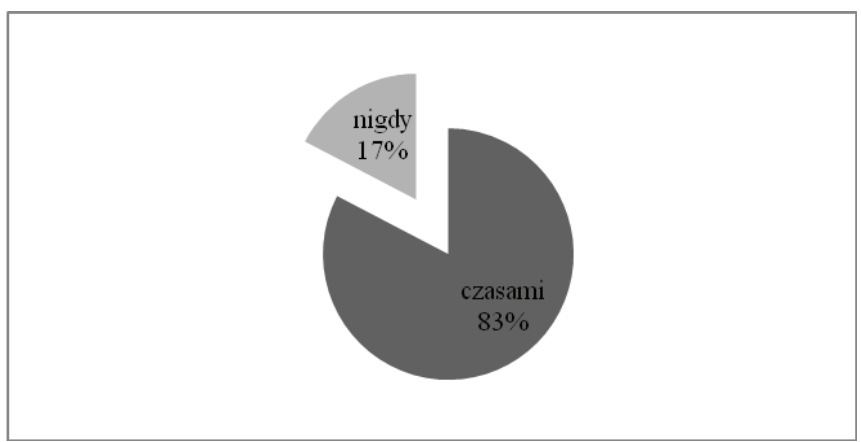

Rys. 2. Otrzymywanie specyfikacji tłumaczeniowej - jak często jest podawana w zadaniach tłumaczeniowych

Najwięcej, bo 47,8\% ankietowanych wybrało „raczej nie”, a po $21,7 \%$ „nie mam zdania” i „raczej tak”. Odpowiedzi skrajne, „zdecydowanie tak” i „zdecydowanie nie”, zyskały po 4,3\% każda.

Wyniki badań, w odniesieniu do analizowanej próby, wydają się sugerować słabe powiązanie teorii dydaktyki przekładu z praktyką kształcenia, ponieważ studentom, według ich deklaracji, znane jest pojęcie specyfikacji tłumaczeniowej, natomiast nie jest ono często stosowane w praktyce. Nie można też wykluczyć nieznajomości pojęcia, gdyż brak odpowiedzi „nie znam" może wynikać z niechęci do przyznania się do swojej niewiedzy. Znajomość pojęcia może być też natury teoretycznej, skoro aż prawie połowa ankietowanych zdecydowanie nie łączy błędu w tłumaczeniu z nieprzestrzeganiem specyfikacji, a ponad $20 \%$ nie ma w tej sprawie zdania. Pojawia się w związku z tym pytanie o koncepcje „dobrego tłumaczenia”, którymi kierują się studenci. W ujęciu funkcjonalistycznym nadrzędnym źródłem kryteriów dla oceny tłumaczenia jest specyfikacja tłumaczeniowa (por. Nord 2006).

Oczywiście trudno wyciągać uogólniające wnioski na podstawie niewielkiej próby. Należy jednak zaznaczyć, że wśród ankietowanych byli absolwenci i obecni studenci kierunków filologicznych renomowanych uczelni państwowych i prywatnych $\mathrm{z}$ aspiracjami. Przyjmując, że badania oddają nawet w jakimś niewielkim stopniu praktykę nauczania przekładu praktycznego, sytuację taką można łączyć z sytuacją polskiej dydaktyki przekładu. Nie jest to zaskakujące, zważywszy na tradycyjne i filologiczne metody, jakimi byli kształceni obecni nauczyciele przekładu, raczej skromną, aczkolwiek powięk- 
szającą się ofertę materiałów dydaktycznych oraz brak form instytucjonalnego kształcenia i dokształcania nauczycieli przekładu. Warto zaznaczyć, że podobne tendencje w nauczaniu tłumaczenia i rozbieżności między komponentami teoretycznymi a praktycznymi wykazały badania Margherity Ulrych (2005), które objęły ukierunkowane zawodowo programy kształcenia tłumaczy w Europie i USA ${ }^{10}$. W ramach kształcenia teoretycznego zdecydowanie najczęściej wymieniane były ujęcia funkcjonalistyczne (po lingwistycznych) (Ulrych 2005: 20) ${ }^{11}$, natomiast założenia tychże ujęć w praktyce nie zawsze były przestrzegane, na przykład w odniesieniu do specyfikacji tłumaczeniowej (np. 68\% respondentów podawało źródło tekstu wyjściowego, a 63\% odbiorcę tekstu docelowego) (Ulrych 2005: 11).

\section{Podsumowanie}

Specyfikacja tłumaczeniowa to ważny, a nawet niezbędny element każdego zadania tłumaczeniowego zarówno w kontekście zawodowym, jak i dydaktycznym. Teoria (dydaktyki) przekładu jednoznacznie podkreśla znaczenie specyfikacji jako narzędzia, które informując o kontekście recepcji i przeznaczeniu tłumaczenia, ukierunkowuje wybory tłumacza i umożliwia ocenę przekładu. Takie założenia teoretyczne znajdują częściowe odzwierciedlenie w przeanalizowanych podręcznikach tłumaczeniowych zawierających ćwiczenia praktyczne adresowanych do użytkowników języka polskiego. Należy zaznaczyć, że oferta tego typu publikacji nawet dla najpopularniejszego obecnie języka angielskiego pozostaje skromna i przeanalizowane podręczniki mają bez wątpienia charakter prekursorski. Z kolei przeprowadzone badania empiryczne, które objęły absolwentów studiów filologicznych pokazują, że studenci znają pojęcie instrukcji tłumaczeniowej, ich zdaniem jest ona jednak rzadko podawana w ćwiczeniach tłumaczeniowych. Zakłada się zatem idealistycznie, że tekst wyjściowy dostarcza wszystkich informacji potrzebnych do jego przekładu. Sugeruje to, że nauczanie tłumaczenia w niektórych uczelniach ma w dużym stopniu charakter filologiczny i tylko w pewnym stopniu nawiązuje do realnych zawodowych uwarunkowań przekładu. Rozpiętość między teorią i metodologią a praktyką w niektórych kontekstach formalne-

\footnotetext{
${ }^{10}$ Badania objęły 41 instytucji kształcących tłumaczy, miały one formę rozbudowanego kwestionariusza i zbierały dane bezpośrednio od instytucji.

${ }^{11}$ Podobną hierarchię wśród najczęściej uczonych teorii przekładoznawczych wykazały badania Sakamoto (2012).
} 
go nauczania przekładu wydaje się znaczna. Tłumaczenie bez specyfikacji to tłumaczenie w próżni. I nie jest już oczywiste, dla kogo tłumaczymy, w jakim celu i w jakiej sytuacji komunikacyjnej.

\section{Podręczniki tłumaczeniowe}

Belczyk, A., 2004, Poradnik tłumacza z angielskiego na nasze, Kraków.

Belczyk, A., 2009, Poradnik tłumacza, Kraków.

Berezowski, L., 2008, Jak czytać i rozumieć angielskie umowy. Praktyczny przewodnik, Warszawa.

González Davies, M., 2004, Multiple Voices in the Translation Classroom, Amsterdam-Filadelfia.

Hervey, S., Loughridge, M., Higgins, I., 2006, Thinking German Translation. A Course in Translation Method, 2 wyd., Londyn-Nowy Jork.

Jeglińska, B., Ndiaye, I.A., 2012, Podręcznik dla tłumaczy języka rosyjskiego. Postępowanie przygotowawcze i sq̨owe, Olsztyn.

Jopek-Bosiacka, A., 2006, Przekład prawny i sadowy, Warszawa.

Piotrowska, M., 1997, Learning Translation, Learning the Impossible? A Course of Translation from English into Polish, 1 wyd., Kraków.

Schäffner, Ch., Wiesemann, U., 2001, Annotated Texts for Translation: English-German: Functionalist Approaches Illustrated, Clevedon.

Skibińska, E., 2001, Inaczej mówiąc... Tłumaczenie z francuskiego na polski, Wrocław.

\section{Literatura}

Albin, J., 2011, „Produkcja tekstu turystycznego: kto i dla kogo?”, [w:] Przekład jako produkt $i$ kontekst jego odbioru, I. Kasperska, A. Żuchelkowska (red.), Poznań, s. 87-97.

Brzozowski, J., 2011, Stanać po stronie tłumacza. Zarys poetyki opisowej przekładu, Kraków.

Fraser, J., 2000, „The Broader View: How Freelance Translators Define Translation Competence", [w:] Developing Translation Competence, Ch. Schäffner, B. Adab (red.), Amsterdam-Filadelfia, s. 51-62.

Gentzler, E., 2001, Contemporary Translation Theories, 2 wyd., Clevedon.

Grygoruk, A.Z., 2005, „Pragmatic and Cultural Problems in Translating. H. Clark and A.L. Estin's »Marital Relations"”, [w:] Linguodidactica, XIV, s. $61-74$. 
Hague, D., Melby, A., Zheng, W., 2011, „Surveying Translation Quality Assessment. A Specification Approach", [w:] The Interpreter and Translator Trainer, 5 (2), s. 243-267.

Hönig, H., 1998, „Positions, Power and Practise: Functionalist Approaches and Translation Quality Assessment", [w:] Translation and Quality, Ch. Schäffner (red.), Clevedon, s. 6-34.

Hulst, J., Lentz, L., 2001, „Public Documents in a Multilingual Context”, [w:] Reading and Writing Public Documents: Problems, Solutions, and Characteristics, D. Janssen, R. Neutelings (red.), s. 85-103.

Klein-Braley, C., 1996, „Teaching Translation, a Brief for the Future”, [w:] Teaching Translation in Universities, P. Sewell, I. Higgins (red.), Londyn, s. 15-30.

Limon, D., 2010, „Translators as Cultural Mediators: Wish or Reality? A Question for Translation Studies", [w:] Why Translation Studies Matters, D. Gile, G. Hansen, N. Pokorn (red.), Amsterdam-Filadelfia, s. 29-40.

Nord, Ch., 2005 (1988), Text Analysis in Translation: Theory, Methodology, and Didactic Application of a Model for Translation Oriented Text Analysis, 2 wyd., Amsterdam-Nowy Jork.

Nord, Ch., 2006, „Translationsqualität aus funktionaler Sicht”, [w:] Übersetzungsqualität: Kritik, Kriterien, Bewertungshandeln, L. Schippel (red.), Berlin, s. 11-29.

Paprocka, N., 2009, „Przypisy tłumacza/redakcji w przekładach prasy (na przykładzie tłumaczeń w »Forum «", [w:] Przypisy tłumacza, E. Skibińska (red.), Wrocław, s. 175-196.

Piotrowska, M., 2007a, Proces decyzyjny tłumacza. Podstawy metodologii nauczania przekładu pisemnego, Kraków.

Piotrowska, M., 2007b, „Polska Bibliografia Przekładoznawcza”, [w:] eadem, Proces decyzyjny tłumacza. Podstawy metodologii nauczania przekładu pisemnego, Kraków, s. 184-196.

Piotrowska, M., 2007c, „Podręcznik do tłumaczenia - przydatne narzędzie dydaktyczne czy utopia?", [w:] Warsztaty Translatorskie, IV, Lublin-Ottawa, s. 311-323.

Pym, A., 2011, „Translation Research Terms: a Tentative Glossary for Moments of Perplexity and Dispute", [w:] Translation Research Projects, 3, A. Pym (red.), Tarragona, s. 75-110.

Reiß, K., Vermeer, H.J., 1984, Grundlegung einer allgemeinen Translationstheorie, Tybinga.

Sakamoto, A., 2012, „Teaching Translation Theory, but which Theory? Results of Preliminary Questionnaire Surveys" (prezentacja na konferencji didTRAD, First International Conference on Translation, Barcelona 2012). 
Skibińska, E., 2009, „O przypisach tłumacza: wprowadzenie do lektury”, [w:] Przypisy tłumacza, E. Skibińska (red.), Wrocław, s. 7-19.

Ulrych, M., 2005, „Training Translators - Programmes, curricula, practices”, [w:] Training for the New Millennium. Pedagogies for Translation and Interpreting, M. Tennent (red.), Filadelfia, s. 3-33.

Yilmaz Gümüş, V., 2008, „A Functionalist Approach to Syllabus Design in Translator Training", [w:] Thinking Translation: Perspectives from Within and Without, R. Parker, K. Guadarrama (red.), Boca Raton, s. 207-215.

\section{Translation brief as a tool for contextualization of translational activity - between theory and practice of translator training \\ Summary}

The aim of the article is to discuss the concept of translation brief from the perspective of translation pedagogy and investigate how theoretical premises are reflected in the Polish translator training practice. Theoretically speaking, the notion of Auftrag ('commission') has been widely used and propagated by the functionally oriented Skopostheorie. Translation pedagogy stresses the significance of translation brief. For instance, Nord emphasizes that it should form an integral part of each translation assignment (2006). Developing the ability to decode and interpret the translation brief, often given implicitly, belongs to important aspects of translator training. The translation brief provides information that guides both translator's decisions when it comes to translation and teachers' or evaluators' decisions in terms of assessment. From the practical perspective, to gain a view of the Polish translator training practice, selected translation textbooks were analyzed and a questionnaire survey was conducted. The analyzed textbooks partially reflect the significance which translation pedagogy assigns to the translation brief which, to some extent, is accounted for by different textbook concepts and designs. The most explicit translation briefs are part of exercises in E. Skibińska’s textbook for Polish-French translation (Inaczej mówiąc...). The results of the survey conducted among students - graduates of BA language studies with translation component - demonstrate that the respondents are familiar with the notion of the translation brief, however the majority of the respondents $(83 \%)$ received translation brief sometimes with their translation assignments while $17 \%$ - never. The respondents also generally do not link the notion of translation error with a transgression of the brief. The survey had a pilot character and included a small sample of respondents, yet it seems to indicate that the notion of translation brief does not play a prominent role in the translation classroom in the Polish setting. 